Institute for Laboratory Astrophysies (Boulder, Colorado) during September 1962 (Pp. iv + 66. Washington, D.C.: Government Printing Office, 1963. 40 cents). The material for the first four lectures on the impact parameter formulation of the theory of atom-atom collisions, the application of the first Born approximation, slow charge transfer, and charge transfer in other cases, respectively, was largely taken from the work of $D . R$. Bates and was presented for pedagogic purposes only. The other two lectures, dealing with further remarks on charge transfer and the ionization of atomic systems by fast protons, contain original material. The numerical results quoted are taken, in part, from at present unpublished work by M. B. McElroy (Belfast), Rudd and Jorgenson (University of Nebraska) and the author.

\section{Seismology in New Zealand}

Is addition to the main earthquake observatory at Wellington, the New Zealand Department of Scientific and Industrial Research operates stations at some sixteen other places, together with seismographs at Hallett Station and Scott Base in Antarctica. Records of observations are given in the reports for $1955-57$, now available (New Zealand Department of Scientific and Industrial Research: Geophysics Division. Wellington: Government Printer). During 1955, 84 shocks were reported felt by people in New Zealand, and one in the Cheviot region did minor damage. Most of these epicentres were in or near New Zealand, but on February 27 an earthquake in the Kermadec Islands (magnitude about 8) was felt in Tolaga Bay and in Wellington. During 1956, 131 earthquakes were felt in New Zealand, including two which did some damage. The most severe was on December 28 between Opotiki and Tolaga Bay (magnitude 6.4) and the other occurred on March 2 some 10 miles north-west of Tokaanu (magnitude 5.3). During 1957, 88 earthquakes were reported to be felt in New Zealand. The shock of December 31 (magnitude 6.6) had an epicentre about 100 miles west of Milford Sound. Damage to chimneys occurred as far west as Dunedin. Minor damage was done by earthquakes on February 22 in the Ohakune-Raetihi district, on March 13 from the Bay of Plenty to Greymouth, and on September 26 between New Plymouth and Wellington. The earthquake reports for 1958 and 1959 are not yet ready, but during 1960 two earthquakes caused minor damage. That on May 25 had an epicentre at sea some 20 miles north of Milford Sound, and that on February 21 was north of Canterbury. Two earthquakes from foci estimated at 370 miles depth occurred on March 23 under N. Taranaki.

In order to facilitate the study of near earthquakes, G. A. Eiby and M. G. Muir, of the Wellington Seismological Observatory, have compiled some most convenient seismological tables from the Jeffreys-Bullen tables (New Zealand Department of Scientific and Industrial Research: Geophysics Division. Tables to Facilitate the Study of Near Earthquakes. Seismological Observatory Bulletin S-109. Pp. 31. Wellington: Government Printer, 1961). These are: travel time of $P$ for a given $S-P$ interval; distances corresponding to given times of $P, S$ and $S-P$; distances corresponding to given travel times of $P$ and $S$; phases due to crustal structure $\left(P g, P^{*}, S g, S^{*}\right)$; intervals between $P n, S n$ and crustal phases. They also give a nomogram for earthquake magnitudes after Richter.

\section{Ultra-structure of Nucleoli and Chromosomes in Normal and X-irradiated Liver Cells}

Electron microscope studies on chromosome structure, although fruitful, have never fulfilled the somewhat optimistic hopes which were originally held out for their use in this particular biological field. The difficulties which have been encountered are not simply due to poor fixation, but result from the lack of contrast between chromosome structures and other nuclear materials. Tho use of 'Araldite' embedding coupled with phosphotungstic acid staining is reported by J. M. G. Davis, of the Department of Radiotherapeutics, University of Cambridge, to overcome partly this problem of nuclear contrast and to make possible studies on changes in chromosome and nucleolar structure during cell development (Phil. Trans. Roy. Soc., B, 291; May 16, 1963. 21s. or 3.15 dollars). He describes the changes observed in these structures in rat liver cells stimulated to undergo mitosis by partial hepatectomy, observations being made during the early stages of regeneration and throughout mitosis in both normal and X-irradiated animals. A relation was shown to exist between a change in nucleolar structure from a compact to a diffuse state, due apparently to the loss of pars amorpha, and the formation of new double membraned elements of the endoplasmic reticulum (alpha cytomembranes). The suggested relationship between these two events is reinforced by the observation that shortly after the irradiation of animals with $450 \mathrm{r}$. of $X$-rays, both the formation of new alpha cytomembranes and the correlated nucleolar changes are inhibited. This is an important observation, particularly in view of the present interest in the transfer of ribonucleoprotein from the nucleus (nucleolus) to the cytoplasm. It is also of interest to note that this is one of the first reports demonstrating an inhibiting effect of X-rays on a normal sequence of changes in nuclear ultra-structure, and that this inhibition was evident in the first few hours after irradiation. The chromosome studies reported showed that at prophase each chromosome appeared as a strand, $1000 \AA$ in diameter, made up of a dense aggregate of a number of thin $100 \AA$ fibres. In mitotic cells fixed $15-30$ min after an X-ray dose of $450 \mathrm{r}$., no ultra-structural changes could be demonstrated in the chromosome material, but with high doses of $2,000 \mathrm{r}$. a change in the density of packing of the $100 \AA$ fibres was noted together with some indications of fragmentation of metaphase and anaphase chromosomes.

\section{Nomad Fulani}

A MONOGRAPH, published under the ægis of the Institut d'Ethnologie, Paris, deals with the social structure and economy of the Wodaabe Fulani, who form the bulk of the nomadic Fulani inhabiting the Sahel zone between the Nigerian boundary and the desert and steppes of the Air region of the central Sahara (Travaux et Mémoires de l'Institut d'Ethnologie. Nr. 64: Peuls Nomades: Étude Descriptive des Wodaabe du Sahel Nigérien. Par Mag. guerite Dupire. Pp. viii $+336+27$ planches. Paris: Institut d'Ethnologie, Musée de l'Homme, 1962. 45 franes). The fifty-page introduction, which summarizes the work of other people and which attempts a description of the physical type of the Fulani and of their zebu cattle, is based on quite inadequate biometrical data in the case of the human types and on purely hypothetical migration routes in the case of their beasts. The author is on surer grounds when she comes to her own material, and she divides it into four parts, which deal respectively with the economy, the domestic cycle, Fulani marriage, and with Wodaabe lineage and tribal organization. There are twenty-four plates, fifteen diagrams and sketch maps and one very large map giving details of group migrations and of transhumance routes in the area. Altogether it forms a very valuable addition to Fulani ethnography, the more so since a complementary study of the Wodaabe living south of the Nigerian border has already been made by D. J. Stenning (Savannah Nomads. International African Institute, 1959).

\section{The Royal Scottish Museum}

With the approval of the Scottish Education Department, a panel of honorary curators has been appointed at the Royal Scottish Museum, Edinburgh. In the report 